\author{
УДК 911.9 \\ doi: $10.15407 /$ ugz2016.04.022
}

\title{
В.В. Удовиченко
}

Київський національний університет імені Тараса Шевченка

\section{ОСОБЛИВОСТІ АНТРОПОГЕННИХ ТРАНСФОРМАЦІЙНИХ ПРОЦЕСІВ ЛІСОСТЕПОВИХ ЛАНДШАФТНИХ КОМПЛЕКСІВ ЛІВОБЕРЕЖНОЇ УКРАЇНИ (НА ПРИКЛАДІ ТЕСТОВОЇ ДІЛЯНКИ ДОСЛІДЖЕННЯ)}

\begin{abstract}
Мета дослідження - відобразити специфічні риси особливостей прояву трансформаційних процесів, властивих лісостеповим ландшафтним комплексам території Лівобережної України на прикладі ділянки дослідження, що презентує Сумську схилово-височинну фізико-географічну область. Ґрунтується це дослідження на основі збору, верифікації й аналізу даних про структуру актуальних систем природокористування за системою басейнових ландшафтних одиниць. Специфіку трансформаційних процесів розглянуто за групами ландшафтних комплексів: їх літо-, гігро-, педо- та фітоваріантами. Крім того, увагу акцентовано на можливості оцінювання таких параметрів басейнових систем як лісистість, заболоченість, розораність, сельбищність залуженість; використання отриманих результатів для обґрунтування заходів з ландшафтного планування територій. Новизна дослідження: за укладеною авторською схемою басейнових територіальних структурних одиниць у масштабі 1:200 000 відповідно до характеру й інтенсивності антропогенних впливів визначено та вперше закартографовано класи ландшафтних комплексів, які $\epsilon$ відображенням специфічних рис трансформації території тестової ділянки дослідження.
\end{abstract}

Ключові слова: ландшафрт; лісостеповий комплекс; антропогенна трансформація; рівень трансформації.

\section{V.V. Udovychenko}

Taras Shevchenko National University of Kyiv

THE SPECIFICITY OF ANTHROPOGENIC TRANSFORMATIONAL PROCESSES WITHIN FOREST-STEPPE LANDSCAPE COMPLEXES OF THE LEFT-BANK UKRAINE(ON THE EXAMPLE OF THE TESTED RESEARCH AREA)

The results presented in this article are connected to the specific features of transformational processes which take place within forest-steppe landscape complexes of the Left-Bank Ukraine and research area within the Sumy slope-elevated physiographic region. This research is grounded on the collection, verification and data analysis of the actual system of natural-resource management structure according to the system of basin landscape units. Specificity of transformational processes is taken into account due to the group of landscape complexes such as litho-, hydro-, pedo- and fitovariant. Also, emphasis is placed on the opportunity to estimate for this purpose such parameters of basin systems as the percentage of forest land, wetland, arable land, residential area, and meadow land; the necessity of using obtained results for the landscape planning tools validation.

Keywords: landscape; forest-steppe complex; anthropogenic transformation; transformational level.

\section{Актуальність теми дослідження}

Вивчення специфіки та ступенів антропогенної зміненості певних ландшафтних комплексів $\epsilon$ важливим дослідницьким етапом, спрямованим на визначення сукупності актуальних функцій природних систем та здатності останніх виконувати задані функції.

Аналіз антропогенної трансформації будьякої території безпосередньо пов'язаний з визначенням видів та інтенсивності антропогенного навантаження на окремі компоненти природи, а також природні комплекси загалом, та являє собою ключовий етап оцінювання екологічної ситуації території - важливої складової розроблення й впровадження ландшафтно-планувальних заходів.

Цей напрям досліджень не втрачає актуальності й у контексті досліджень ландшафтно-планувального типу, адже саме знання про причини, напрямки, глибину антропогенної (техногенної) трансформації ландшафтів, зокрема за басейновими територіальними структурними одиницями, території дослідження дають глибоке уявлення про їх фактичний стан, є підгрунтям виявлення “конфліктних" територій, а також визначення тих комплексів, що втратили свою стійкість та мають низький потенціал самовідновлення, а в результаті застосування басейнового підходу - створюють можливості для передбачення напрямків та векторів перебігу фізико-географічних (часто - несприятливих) процесів.

3 іншого боку, тривале й інтенсивне освоєння природного середовища та зростання інтенсивності антропогенних впливів на природні ландшафти регіону дослідження виводять проблему дослідження їх трансформації під дією цих чинників у ранг першочергових та актуальних, підвищуючи необхідність та значущість аналізу масштабів змін ландшафтних комплексів, зокрема в межах басейнової територіальної структури, у тому числі для потреб розроблення й втілення ландшафтно-планувальних заходів.

\section{Стан вивчення питання}

Головні аспекти вивчення антропогенної зміненості ландшафтних комплексів, основні наукові підходи, принципи та методи аналізу й визначення антропогенних навантажень, антропогенного перетворення ландшафтів було закладено, розробле- 
но та поглиблено у роботах Мількова Ф.М. [10 та ін.], Ісаченка А.Г. [5 та ін.], Шищенка П.Г. [15, 16], Гродзинського М.Д. [1, 2], Денисика Г.I. [3], Малишевої Л.Л. [9] та інших. У працях цих та інших учених було розроблено й окремі кількісні методи оцінювання ступеня антропогенного перетворення ландшафтів.

Тема взаємодії суспільства і природи є пріоритетною у дослідженнях Інституту географії НАН України, зокрема у руслі розроблення концепції та стратегії збалансованого розвитку. Результати їх узагальнені в одноосібних та колективних монографіях (напр. [8, 14], публікаціях в періодичних виданнях, картографічних творах, зокрема Національному атласі України [13].

Серед робіт регіонального характеру, які б розкривали особливості прояву трансформаційних процесів на регіональному та локальному рівнях організації географічного середовища, можна навести колективну монографію [7], яка увійшла до циклу праць, група авторів яких уперше серед географів була удостоєна Державної премії України в галузі науки і техніки 1993 року. Слід зазначити, що робіт, які б стосувалися виявлення антропогенної трансформації ландшафтів певних регіонів бракує, а в розрізі басейнових територіальних структур локального просторового рівня взагалі не виявлено, що і зумовлює актуальність обраної тематики.

М е т а цієї роботи - виявити специфічні риси особливостей прояву трансформаційних процесів лісостепових ландшафтних комплексів території Лівобережної України (на прикладі тестової ділянки дослідження) для потреб визначення рівнів антропогенної трансформації й наступного розроблення та запровадження системи ландшафтно-планувальних заходів у регіоні.

\section{Методи та методика дослідження}

Оцінювання антропогенного перетворення лісостепових ландшафтів ділянки дослідження на території Лівобережної України було виконано на основі збору, верифікації й аналізу даних про структуру актуальних систем природокористування регіону. Вихідною інформацією були фондові матеріали, результати власних польових досліджень та узагальнень. Аналіз трансформації літогенної основи, гідро-, педо- та фітокомпонентів ландшафтних комплексів території дослідження виконано з використанням ГIC-пакету MapInfo Professional 10.0.1. База даних включала інформацію про найбільш значущі види господарської діяльності людини та їх наслідки, пов'язані, зокрема, з гірничодобувною промисловістю, осушувальною меліорацією, житловим та громадським будівництвом, прокладанням шляхів сполучення, сільськогосподарським використанням території, водним господарством, лісівництвом, викладену в різних джерелах ${ }^{1}[4,6,11,12]$ та інших.

При цьому на даному етапі дослідження оцінюванню підлягали лише площинні показники проявів трансформаційних процесів, оскільки саме вони дають можливість розрахувати рівні антропогенного перетворення за отриманими статистичними даними про структуру землекористування. За операційні одиниці для реалізації дослідження прийнято басейнові територіальні системи. Застосування таких методичних прийомів забезпечило можливість виявити внутрішньорегіональні відмінності антропогенної трансформації ландшафтів території дослідження на прикладі тестової ділянки розвитку лісостепових ландшафтних комплексів, а на основі отриманих даних - визначити класи антропогенно змінених ландшафтів, їх варіанти, а також потенціали їх самоочищення, самовідновлення, стійкості та надійності.

\section{Виклад основного матеріалу}

Основним чинником антропогенної трансформації ландшафтних комплексів території дослідження є їх цілеспрямоване перетворення внаслідок господарської діяльності людини шляхом окультурення земель, зміни фітоценотичної структури та видового різноманіття рослинного покриву, структури ландшафтів під час будівництва, прокладання доріг тощо.

Під антропогенною (техногенною) трансформацією ландшафтів та комплексів басейнової територіальної структури розуміють зміненість їх структурних та динамічних особливостей в результаті функціонального використання $[1,2]$.

Дослідний полігон було закладено у лісостеповій частині території Лівобережної України, зокрема в межах Сумської схилово-височинної фізико-географічної області [12]. Це територія 3 багатовіковою історією господарського освоєння та використання, які разом позначилися на структурі й особливостях функціонування ландшафтних комплексів, що сформувалися.

3 метою дослідження напрямків й інтенсивності антропогенної трансформації ландшафтів лісостепової ділянки дослідження території Лівобережної України за басейновою структурою було застосовано розроблену класифікацію, створену на

\footnotetext{
${ }^{1}$ Доповідь про стан навколишнього природного середовища в Чернігівській області за 2012 р. / Держуправління охорони навколишнього природного середовища в Чернігівській області. - Чернігів, 2013 [Електронний pecypc]. Режим доступу: http://www.menr.gov.ua/docs/ activity-dopovidi/regionalni/rehionalni-dopovidi-u-2012rotsi/chernigivska_2012.pdf (Дата звернення 25.02.2016). Національна доповідь про стан техногенної та природної безпеки в Україні у 2010 році / Державна служба України 3 надзвичайних ситуацій [Електронний ресурс]. Режим доступу: http://www.mns.gov.ua/content/ nasdopov2010.html (Дата звернення 25.02.2016).
} 


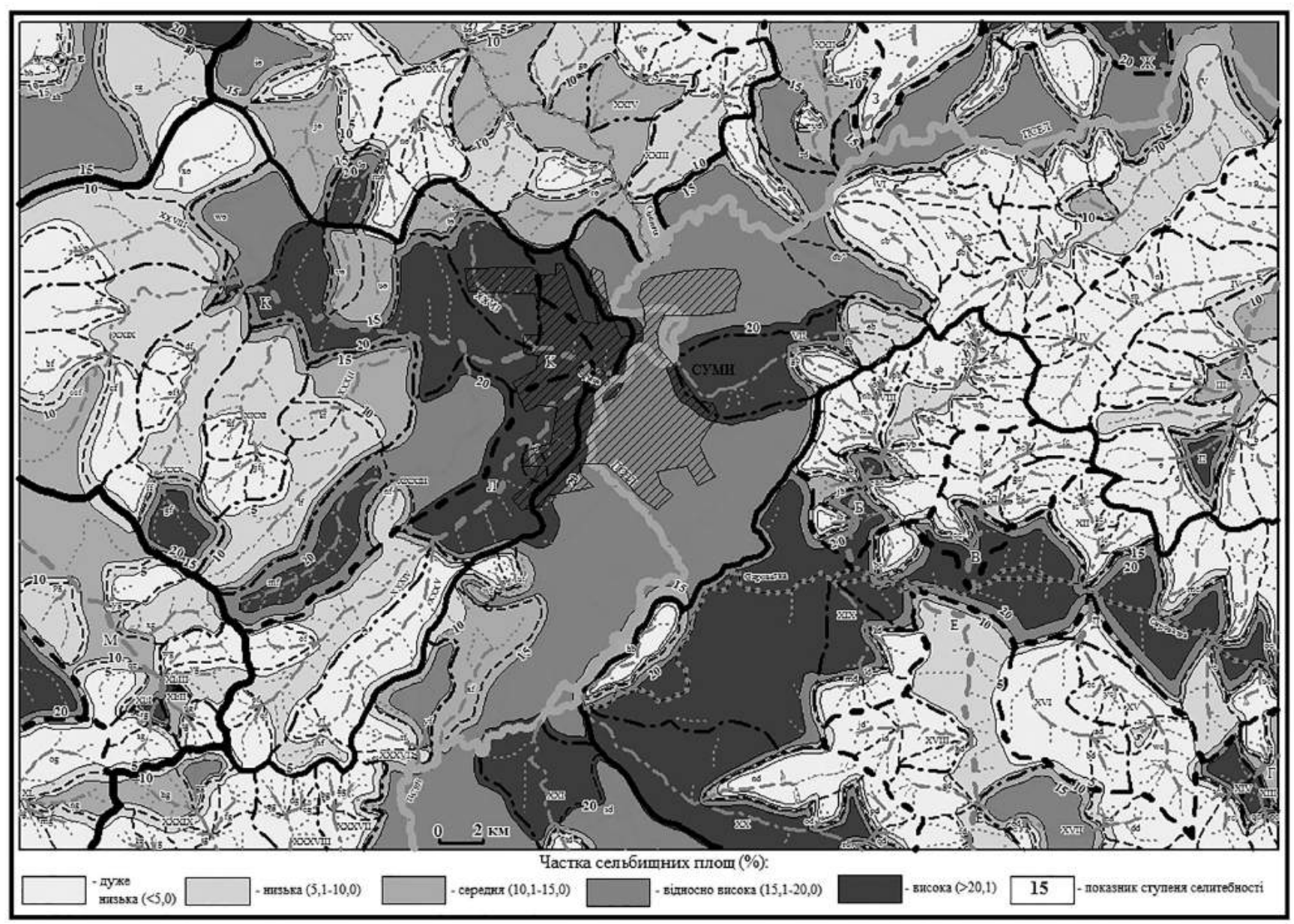

Рисунок 1. Сельбищність басейнових територіальних структурних одиниць ділянки дослідження лісостепових ландшафтних комплексів Лівобережної України (фрагмент)

основі врахування й обгрунтування нерівнозначності антропогенних змін окремих компонентів ландшафтів. Згідно з нею та за результатами здійсненого аналізу структури території дослідження й того, які компоненти ландшафтних комплексів зазнали трансформації насамперед, було виділено літо-, гігро-, педо- та фітоваріантні їх класи .

Найбільше (необоротно) зміненими в межах полігону дослідження є літоваріантні ландиафтні комплекси районів поширення родовищ корисних копалин, що розробляються, сельбищних ландшафтів та інших. Найвищими показники антропогенної трансформації $\epsilon$ для літоваріантних комплексів зі значним ступенем зосередження кар'єрів, об'єктів промислового виробництва, транспортних осей, меліоративних систем та сельбищних територій, на які разом припадає $>80 \%$ площ, та у структурі сучасних ландшафтів яких лісовкритих, заболочених немеліорованих та залужених територій практично немає, або вони мають підпорядковане значення. Відповідно, потенціал самоочищення, самовідновлення, стійкості та надійності цього класу ландшафтів найнижчий 3 можливих, a, отже, саме такі комплекси потребують найпильнішої уваги в процесі розроблення та реалізації ландшафтно-планувальних заходів.
Результати оцінювання антропогенного перетворення ландшафтів, виконаного в кількісних показниках, свідчать про те, що в межах дослідної ділянки поширення лісостепових ландшафтних комплексів території Лівобережної України літоваріантні ландшафти характерні для верхів”ї та нижньої течії р. Рибиця ([I-b-c], [p], [II] - тут і далі індексація відповідає такій, як на рис. 1-3), верхів'їв окремих приток р. Сироватка ([Г-XIV], [ud], [vd], [Д-XV-yc-zc], [XIX-kd], [XX-nd]), верхньої та середньої течіï р. Крупець ([XXI-sd-td]); значних за площею ареалів та практично повсюдно представлених у басейні р. Сумка ([К-XXVII-XXXIII] та [Л-XXXIV-XXXV]), майже суцільно - у басейні pp. Сули та Виру ([XL], [M-XLI-XLIII] та [zg-bh]) (рис. 1).

Серед антропогенно змінених гігроваріантних ландмафтних комплексів найхарактерніші ті, що сформувалися у зонах впливу меліоративних систем. Ступінь їх трансформації варіює залежно від режиму сучасного функціонування гідротехнічних споруд й способу господарського використання меліоративних земель. Для геокомплексів цієї категорії властива повсюдна зміна умов зволоження та, як наслідок, рослинного і грунтового покриву. Найбільш зміненими гігроваріантними ландшафт- 
ними комплексами є меліоровані заплави річок; значно зміненими є ті, в межах яких підтримується функціонування меліоративних систем і здійснюється інтенсивне сільське господарство, найменш зміненими можна вважати такі гігроваріантні комплекси, де внаслідок зменшення інтенсивності господарського використання, припинення функціонування меліоративних систем, заростання й замулення дренажних каналів відбуваються процеси самовідновлення рослинного покриву - формуються лучні та лучно-болотні, частково із чагарниковим ярусом, рослинні угруповання. 3 іншого боку, до антропогенно найменш змінених гігроваріантних ландшафтів відносяться немеліоровані екологічно стійкі болотні комплекси та системи.

Найвищий ступінь заболочення, а, отже, низький - зміненості (в даному випадку без урахування процесів вторинного підтоплення та заболочення), мають гігроваріантні лісостепові ландшафтні комплекси долини р. Псел та нижньої течї р.Крупець ([XX], [XXI] (рис.2).

Невисоким ступенем трансформації характеризуються також гігроваріантні залужені ландшафтні комплекси, найчастіше - заплавні, які використовуються як пасовища та сіножаті. Високим ступенем залуження вирізняються долини рр. Псел, Рибиця та Сироватка 3 витоками їі окремих при ток, а також нижньої течії р. Крупець. Крім того, у вигляді розрізнених ареалів ділянки, що мають високий ступінь залуження, трапляються у басейні річок Олешня та Сумка. Ступінь залуженості також відображено на відповідній карті, яка у цій публікації не представлена.

Педоваріантні ландшафтні комплекси набули розвитку в районах інтенсивного ведення сільського господарства й, відповідно, значної трансформації грунтового покриву. Ступінь останньої змінюється залежно від режиму, способу й інтенсивності використання агроландшафтів, застосування меліоративних засобів і технологій, аж до переформування структури ландшафтів (зокрема - геохімічної) внаслідок, наприклад, внесення надмірної кількості хімічних речовин. 3 іншого боку, трансформація грунтового покриву значно корелює зі змінами рослинності (вирубування лісів, сільськогосподарське використання земель та ін.), режиму зволоження, дефляційними, ерозійними та іншими процесами, які безпосередньо або опосередковано пов'язані 3 господарською діяльністю людини. Найбільш трансформованими педоваріантами ландшафтів $\epsilon$ ті, що мають високий та відносно високий ступінь розораності території (>80\% та 60-80\% відповідно), середній рівень трансформації характерний для комплексів зі ступенем розораності 40-60\%, низький і дуже низький - для комплексів зі ступенем розораності 20-40 та $<20 \%$ відповідно (рис. 3).
У межах лісостепової ділянки дослідження високий ступінь трансформації педоваріантні ландшафти мають у верхів'ях та нижній течії р. Рибиця ([I-b-c], [p]), у басейнах витоків та середньої течії приток р. Сироватка ([Б-іb], [Б-zb]; [Г], [uс], [yc]; [Д-XV-yc-zc]; [E-fd]; [XIX-kd]), у верхній течіï р. Крупець ([XXI-sd-td]) та у вигляді майже суцільних ареалів - в межах долини р. Олешня ([XXVI], [pe-re]), верхньої течії рр. Сумка ([К-we], [K-XXVIII-XXXIII]; [Л-XXXIV-XXXV]), Сула та Вир. Середній рівень трансформації характерним є для педоваріантних лісостепових комплексів середньої течії р. Рибиця ([A-IV]), окремих приток та долини р. Псел ([IV-bb], [db^], [Ж], [XXII]), Сироватка (зокрема, [Б-ІХ], [В], [XII]), а також Олешня ([XXVI-ne]) та Сумка ([K], [K-XXVII], [Л]). Разом 3 тим, низький та дуже низький ступінь трансформації властивий педоваріантним ландшафтам верхів’їв приток р. Рибиця ([IV-j], [IV-k], [IV-m]), верхів 'їв малих приток р. Псел ([V-q-t], [V-v], [y-ab], [VI-cb-db]; [wd]), p. Сироватка ([bc], [B-XI-gc-hc], [XII-kc-lc], [nc], [Г-tc]) та Олешня ([XXII-de], [XXIV-fe-ee], [ge]); нижньої течії р. Крупець ([XXI]).

Формування фітоваріантних ландиафтних комплексів пов'язано, головним чином, із такими видами природокористування, як лісове та сільське господарство. Вони характерні для ділянок, які нині або у недавньому минулому були зайняті лісовими угрупованнями. Райони значного розвитку та невисокого ступеня перетворення фітоваріантних ландшафтів мають високий рівень стійкості, екологічної надійності та самовідновлення. Зміни рослинного покриву, найбільш динамічного та вразливого компонента ландшафту, які мають місце у складі цієї та усіх інших категорій антропогенно трансформованих ландшафтів, яскраво ілюструють вплив на актуальні геосистеми та їх стан різноманітних природних й антропогенних (за своєю природою) процесів. Часто спостерігається тенденція до деградації природних лучних систем - заростання їх деревно-чагарниковою рослинністю та бур'яновими видами трав. Разом 3 тим, на покращених луках, що розвинулися на меліорованих землях, у випадках недостатності застосування агротехнічних заходів, відмічається розвиток бур'янової рослинності, а також розрідження трав'яного покриву.

Отже, природні та природно-антропогенні процеси та їх просторово-часові зміни тією чи іншою мірою трансформують структуру рослинного покриву, збільшуючи частку непокритих лісом земель, похідних угруповань та культурних насаджень, що разом знижує екологічну стійкість фітоваріантних ландшафтів й має бути важливим аргументом розроблення та впровадження відповідних схем планування.

Діапазон модифікацій фітоваріантних, зі змі- 


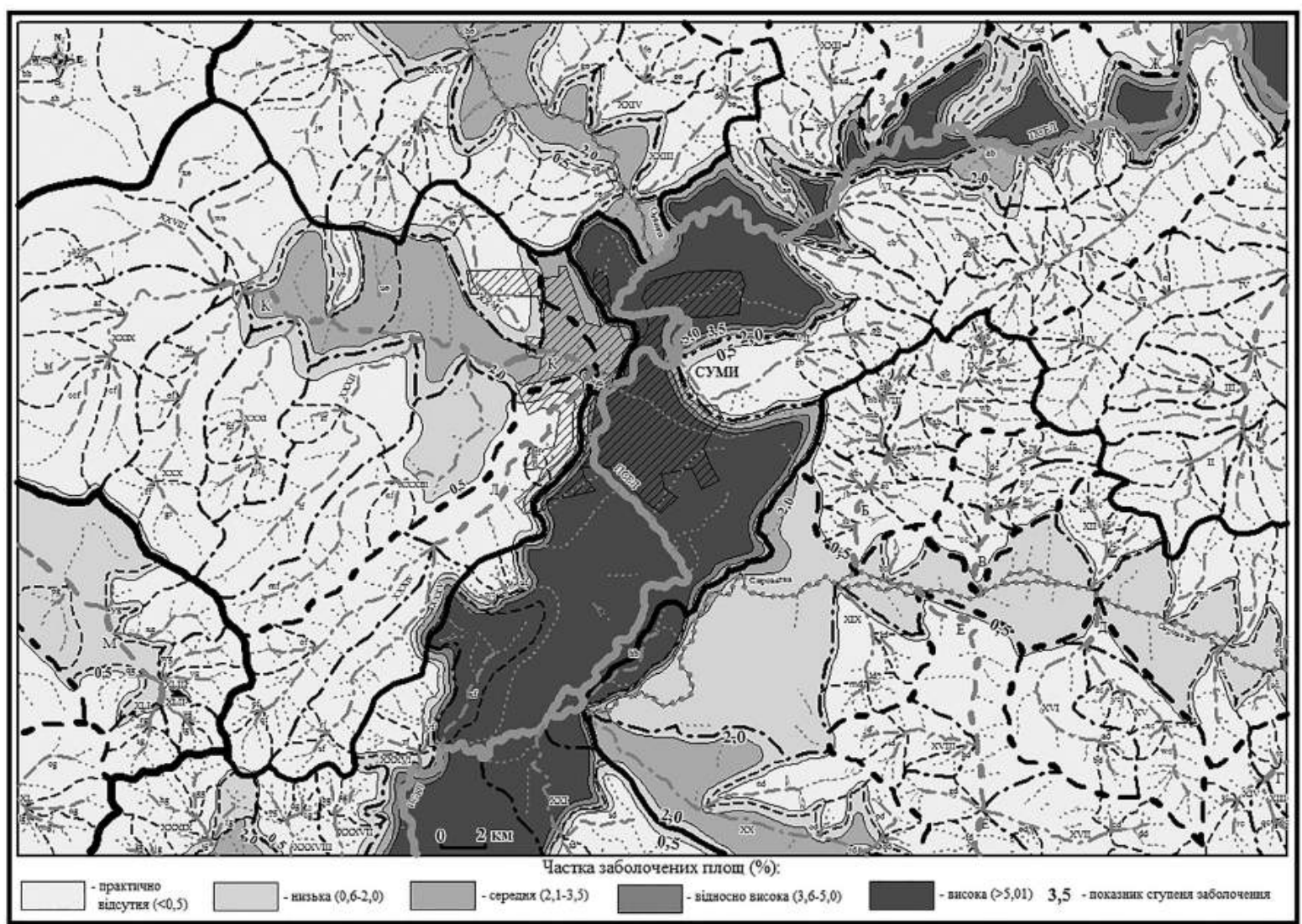

Рисунок 2. Заболоченість басейнових територіальних структурних одиниць ділянки дослідження лісостепових ландшафтних комплексів Лівобережної України (фрагмент)

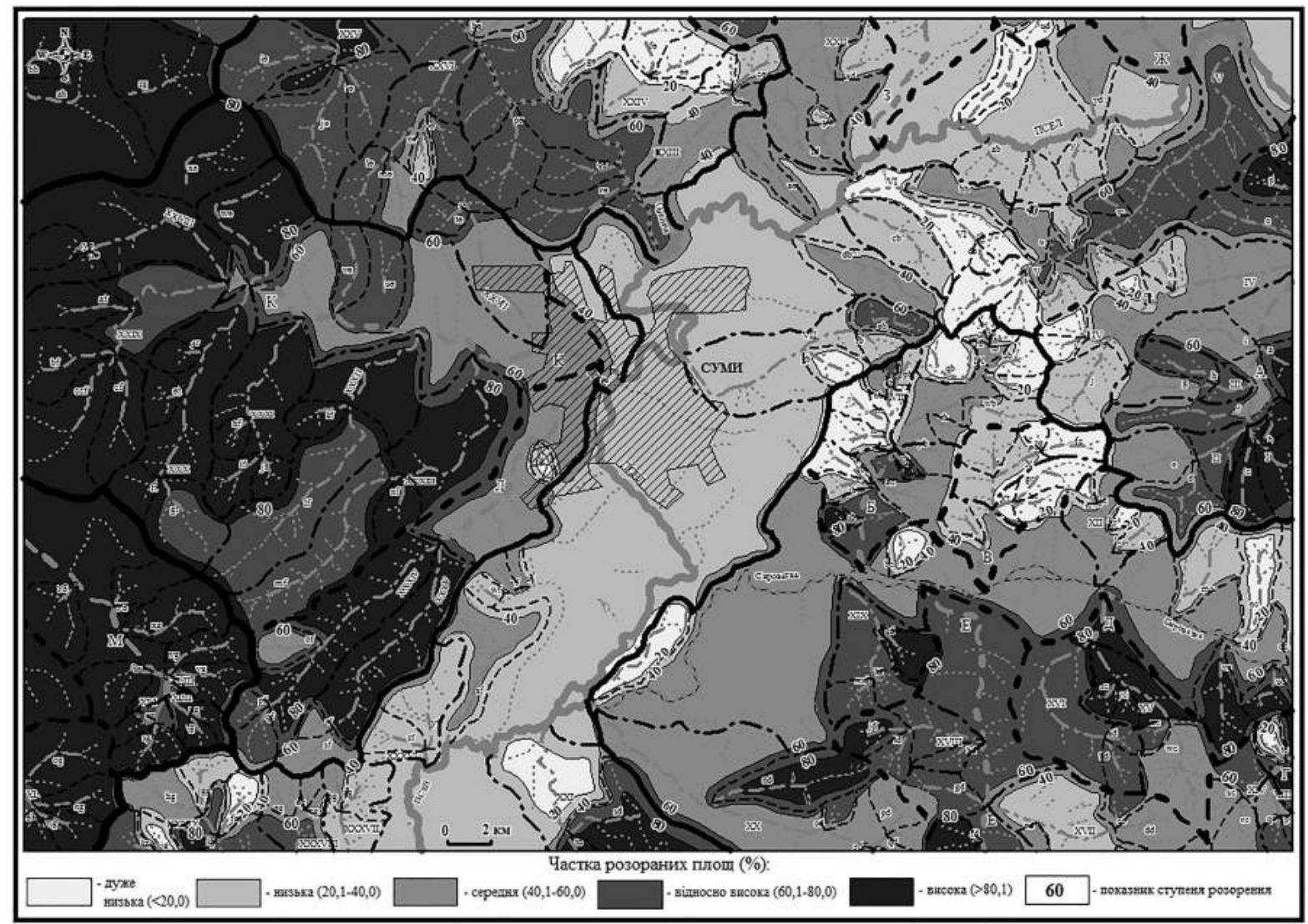

Рисунок 3. Розораність басейнових територіальних структурних одиниць ділянки дослідження лісостепових ландшафтних комплексів Лівобережної України (фрагмент) 


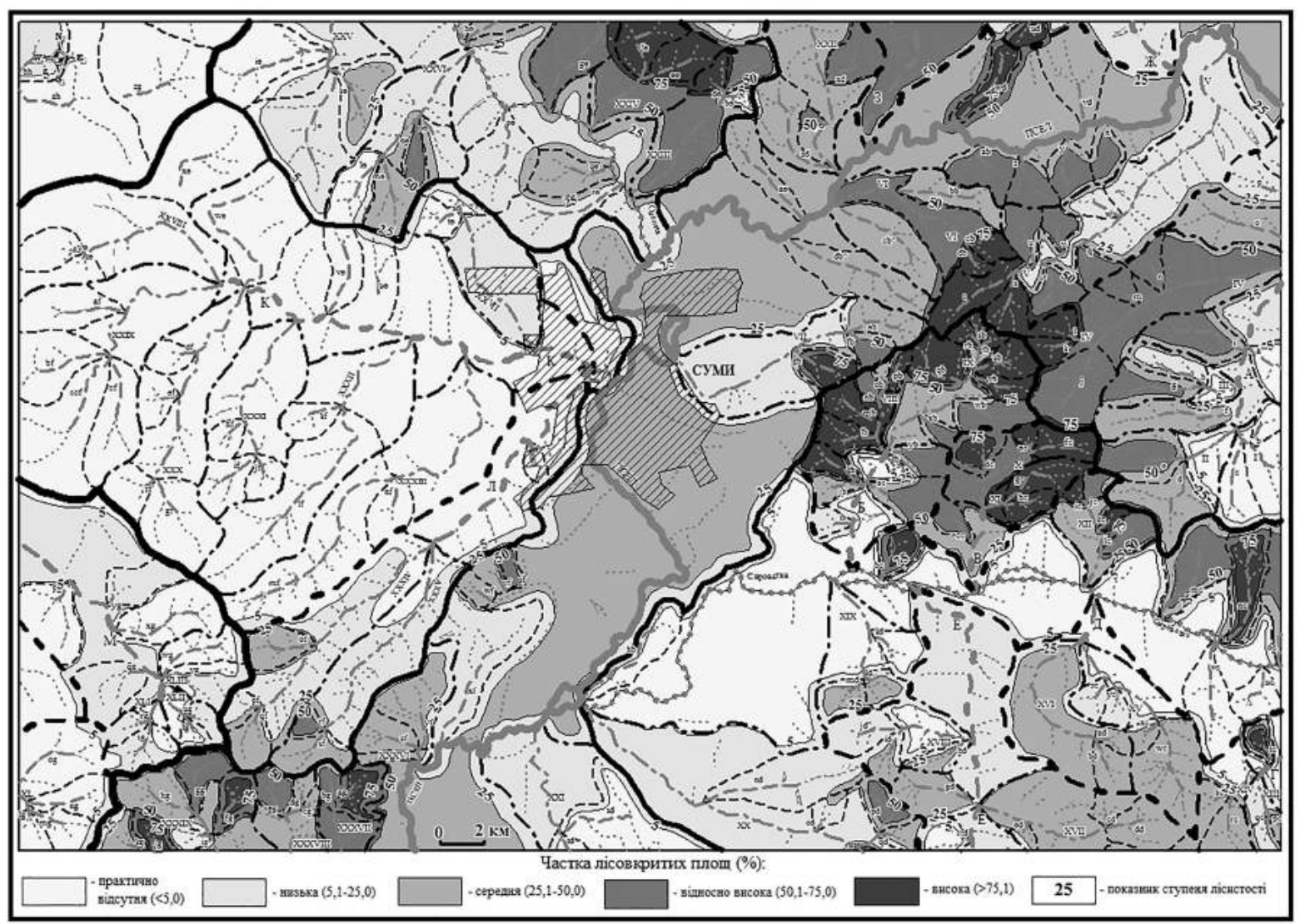

Рисунок 4. Лісистість басейнових територіальних структурних одиниць ділянки дослідження лісостепових ландшафтних комплексів Лівобережної України (фрагмент)

неним рослинним покривом, ландшафтних комплексів коливається від ландшафтів із лісовою рослинністю та синантропними видами у іiі складі, до вторинних луків та агроландшафтів на місці зведених корінних лісів й остепнених луків. Найменш трансформованими $є$ фітоваріантні ландшафтні комплекси, у складі яких є лісова рослинність або остепнені (цілинні) луки. Незважаючи на те, що трансформуючий вплив лісового господарства полягає у зміні типових біоценозів, створенні штучних лісонасаджень, лісові актуальні ландшафти є найменш зміненим варіантом. Вони відповідають природним умовам лісовкритих площ лісостепу та їх стан можна розглядати як найбільш наближений до природного. Найбільшою мірою трансформація фітоваріантних ландшафтних комплексів та значною - фітокомпоненту, пов'язана з використанням їx як сільськогосподарських угідь, особливо як ріллі. Наслідком такого виду природокористування $\epsilon$ повне заміщення зонального типу рослинності, зміни грунтового покриву та його фізико-хімічних властивостей, пов'язані з хімічним забрудненням, втратами гумусу, ущільненням грунтових горизонтів.

У складі лісостепових ландшафтів загальний ступінь лісистості території, порівняно $з$ мішанолісовими, істотно зменшується, при цьому значного поширення набувають фітоваріантні ландшафтні комплекси, що мають низький ступінь лісистості, та високий - трансформації (рис. 4). Такими є витоки р. Рибиця ([a], [I-b-c], [II], [III]), долина р. Сироватка (зокрема, [uc], [vc], [Д], [Д-XV]), середня течія р. Крупець ([sd-td]), окремі притоки р. Олешня ([ie], [le]). Крім того, практично суцільне поширення знелісені комплекси мають у басейні рр. Сумка ([К]), Стрілка ([Л], [Л-tf]), Сула ([XL], [M-pg], [M- XLI-XLII] та інші) та Вир ([zg-bh]). Натомість фітоваріантні ландшафтні комплекси невисокого рівня трансформації, високого ступеня лісистості та екологічно стійкі й надійні у складі лісостепової ділянки набули фрагментарного поширення, займають незначні площі, та представлені у басейнах окремих приток р. Псел ([wd], [XXXVII-ag]), Сироватка ([VIII-kb-pb], [XIX-qb-vb], [bc], [XI-gchc], [nc]) та Олешня ([XXIII-de], [XXIV-ee-fe]).

Виконаний у такий спосіб у масштабі 1:200 000 аналіз трансформаційних процесів, властивих лісостеповим ландшафтним комплексам Лівобережної України, на прикладі тестової ділянки дослідження та басейнових структур у їі межах дав можливість детально проаналізувати статистичні дані й отримати інформацію про співвідношення варіантів ландшафтних комплексів, які мають різний характер і ступені антропогенних перетворень (рис.5), що $є$ важливим вихідним матеріалом для потреб 


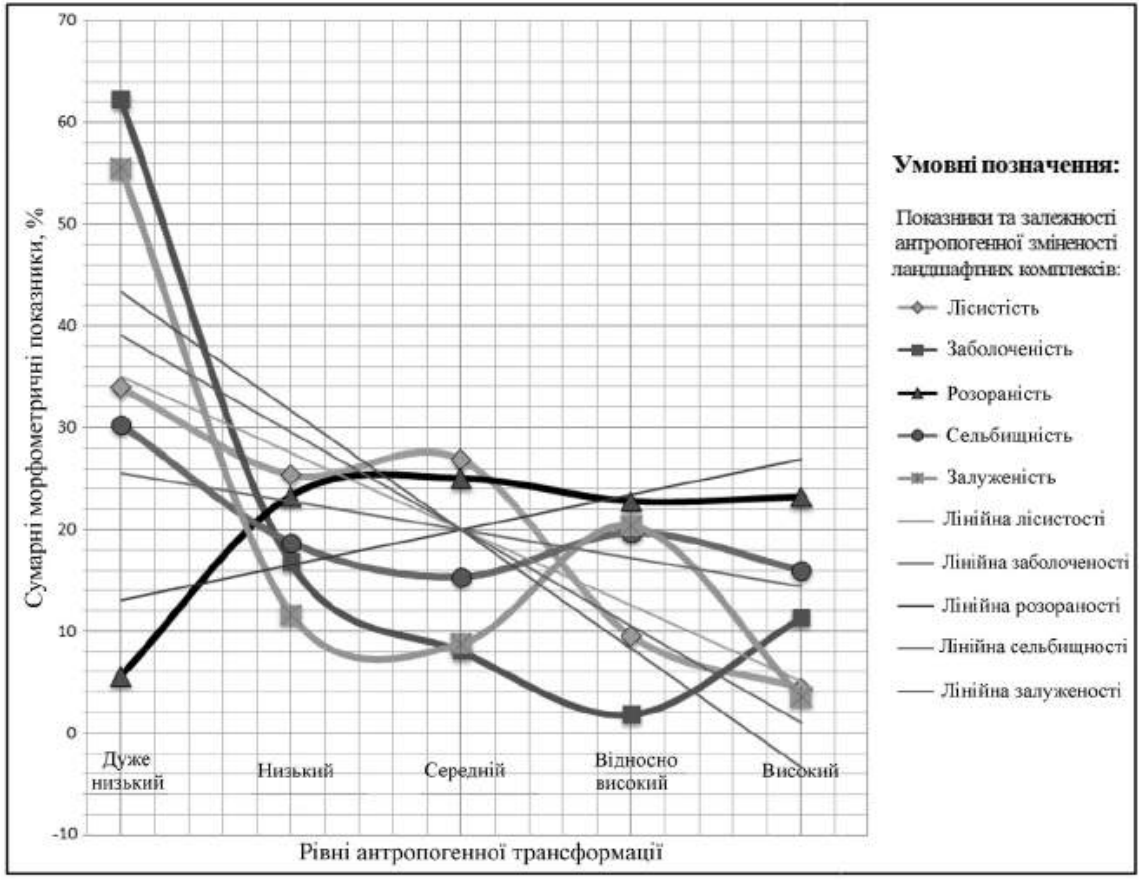

Рисунок 5. Співвідношення та залежності показників трансформаційних процесів (на прикладі тестової ділянки дослідження) оцінювання існуючих відмінностей ступенів трансформації ландшафтів, а також подальшого розроблення ландшафтно-планувальних заходів.

\section{Висновки}

Загальний доволі високий рівень трансформації ландшафтів регіону дослідження зумовлений, насамперед, його інтенсивним землеробським та сельбищним освоєнням. За умови такого ступеня освоєння й відносно незначного розвитку екологічно стійких ландшафтних комплексів, необхідною складовою оптимізації природного середовища $\epsilon$ покращення функціональної організації ландшафтів. І хоча на ландшафти із дуже високим рівнем трансформації припадає незначний відсоток займаних площ $(7,32 \%$ лісостепових комплексів), варто пам'ятати, що негативні наслідки функціонування у їх межах промислових, сельбищних та інших об'єктів поширюються на значні території, що знаходяться у зоні їх впливу. Отже, цей аспект має бути врахованим у контексті запровадження ландшафтно-планувальних заходів.

Новизна цього дослідження полягає в тому, що за укладеною авторською схемою басейнових територіальних структурних одиниць у масштабі 1:200 000 у відповідності до характеру й інтенсивності антропогенних впливів було визначено та вперше закартографовано класи ландшафтних комплексів, які $\epsilon$ відображенням специфічних рис трансформації території тестової ділянки дослідження.

Варто зауважити, що застосовані методичні аспекти оцінювання антропогенної трансформації ландшафтів тестової ділянки території Лівобережної України є важливою базою для визначення інтегральних рівнів їх перетворення господарською діяльністю людини, що є завданням подальших наукових вишукувань з розширенням їх складників.

\section{References [Лimepamypa]}

1. Grodzinskyi M.D. (1993). The basics of landscape ecology . Kyiv: Lybid. [In Ukrainian].

[Гродзинський М. Д. Основи ландшафтної екології: Підручник. - К.: Либідь, 1993. - 224 с.]

2. Grodzinskyi M.D. (1995). Geosystems firmness to the anthropogenic load. Kyiv: Likei. [In Ukrainian].

[Гродзинський М. Д. Стійкість геосистем до антропогенних навантажень. - К.: Лікей, 1995. - 233 с.]

3. Denisyk G.I. (2012). Anthropogenic landscapeology. Part I. Global anthropogenic landscapeology. Vinnitzia: PP TD Edelveis i K. [In Ukrainian].

[ДенисикГ.І. Антропогеннеландшафтознавство: навчальний посібник. Частина І. Глобальне антропогенне ландшафтознавство. - Вінниця: ПП “ТД “Едельвейс і К”, 2012. - 336 с.]

4. Sheliag-Sosonko Yu.R., Dubyna D.V., Vakarenko L.P., Movchan Ya.I., Didukh Ya.P. (2003). Conservation and rational use of Ukraine's biodiversity: state and perspectives. Kyiv: Khimdgest. [In Ukrainian].

[Збереження і невиснажливе використання біорізноманіття України: стан і перспективи / Ю.Р. Шеляг-Сосонко, Д.В. Дубина, Л.П. Вакаренко, Я.І. Мовчан, Я.П Дідух. - К.: Хімджест, 2003. - 248 с.]

5. Isachenko A.G. (1980). Methods of applied landscape research. Leningrad. [In Russian].

[Исаченко А. Г. Методы прикладных ландшафтных исследований. - Л.: Наука, 1980. - 222 с.]

6. Map of spreading exogenous geological processes of the Ukraine's territory (1:500 000). Ed. N.M. Gavrilenko (1995). Kyiv: Geoprognoz. [In Russian]..

[Карта распространения экзогенных геологических процессов территории Украины (М-б 1:500 000) / Гл. ред. Н.М. Гавриленко. - К.: ГГП Геопрогноз, 1995.] 
7. Productive-geographic fundamentals of nature management in the Ukrainian SSR. Kiev Dnepr region. Ed. A.M. Marinich, M.M. Palamarchuk (1988). Kiev: Naukova dumka. [In Russian].

[Конструктивно-географические основы рационального природопользования в Украинской ССР. Киевское Приднепровье / Отв. ред. А.М.Маринич, М.М. Паламарчук. - К.: Наукова думка, 1988. - 176 с.]

8. Rudenko L.H., Maruniak Eu.O., Golubtsov O.H. et al. Ed L.H. Rudenko (2014). Landscape planning in Ukraine. Kyiv: Referat. [In Ukrainian].

[Ландшафтне планування в Україні / Л.Г. Руденко, Є.О. Маруняк, О.Г. Голубцов та ін.; під ред. Л.Г. Руденка. - К.: Реферат, 2014. - 144 c.]

9. Malysheva L.L. (1988). Landscape-geochemical estimation of the ecological state of territories. Kyiv: RVZ Kiivskyi universitet. [In Ukrainian].

[Малищева Л. Л. Ландшафтно-геохімічна оцінка екологічного стану територій. - К.: РВЦ “Київський університет”, 1998. -264 c.]

10. Milkov F.N. (1973). Human and landscapes. Sketches of anthropogenic landscapeology. Moskov: Misl. [In Russian]. [Мильков Ф. Н. Человек и ландшафты. Очерки антропогенного ландшафтоведения. - М.: Мысль, 1973. - 224 с.]

11. National report about state of environment in Ukraine in 2010 (2011). Kyiv: Tzentr ecologichnoji osviti ta informatzii. [In Ukrainian]. [Національна доповідь про стан навколишнього природного середовища в Україні у 2010 році. - К.: Центр екологічної освіти та інформації, 2011. - 254 с.]

12. National report about state of environment in Ukraine in 2011 (2012). Kyiv: Ministry of ecology and natural resourses of Ukraine. [In Ukrainian].

[Національна доповідь про стан навколишнього природного середовища в Україні у 2011 році. - К.: Міністерство екології та природних ресурсів України, 2012. - 258 с.]

13. National atlas of Ukraine. Ed. L.H. Rudenko (2007). Kyiv: DNVP Kartographia. [In Ukrainian].

[Національний атлас України / Гол. ред. Л.Г. Руденко. - К.: ДНВП “Картографія”, 2007. - 440 с.]

14 Ukraine: the main trends in society and nature interaction in the twentieth century (geographical aspect). Ed. L.H. Rudenko (2005). Kyiv: Academperiodica. [In Ukrainian].

[Україна: основні тенденції взаємодії суспільства і природи у ХХ ст. (географічний аспект) / За ред. Л.Г. Руденка. - К.: Академперіодика, 2015. - 308 с.]

15. Shyschenko P.H. (1988). Applied physical geography. Kyiv: Vyscha shkola. [In Russian]. [Шищенко П. Г. Прикладная физическая география. - К.: Выща шк., 1988. - 192 с.]

16. Shyschenko P.H. (1999). Principles and methods of landscape analysis in regional projection. Monography. Kyiv: Fitosotziotzentr. [In Russian].

[Шищенко П. Г. Принципы и методы ландшафтного анализа в региональном проектировании. Монография. - К.: Фитосоциоцентр, 1999. - 284 с.]

Стаття надійшла до редакції 30.06.2016

\author{
УДК 911.2/3 \\ doi: $10.15407 /$ ugz2016.04.029 \\ О.Г. Голубиов \\ Інститут географрії Національної академії наук України, Київ
}

\title{
ЛАНДШАФТНЕ ПЛАНУВАННЯ ЯК ІНСТРУМЕНТ РЕАЛІЗАЦІЇ ЕКОЛОГІЧНИХ ВИМОГ У ТЕРИТОРІАЛЬНЕ ПЛАНУВАННЯ УКРАЇНИ
}

Мета публікації - представлення методичних підходів і напрямів впровадження матеріалів і результатів ландшафтного планування в територіальне планування. Ландшафтне планування, як галузеве природоохоронне планування землекористування, розглядається як основа для реалізації в територіальному плануванні екологічних вимог, урахування яких передбачене в законодавстві. Результати ландшафтного планування можуть бути застосовані для розроблення рекомендацій і посилення аргументації прийняття планувальних рішень у зв'язку з особливостями природних умов і запобігання екологічних проблем. Ландшафтно-планувальні документи, що розробляються на різних рівнях адміністративно-територіального устрою, за детальністю і ступенем узагальнення результатів відповідають територіальним планам. Проте, необхідна адаптація ландшафтно-планувальних формулювань до прийнятої в територіальному плануванні термінології і планувальних категорій. Інтеграція ландшафтного планування можлива за сценаріями первинного (без розробки окремого ландшафтного плану) і вторинного (інтеграція вже отриманих результатів) включення. Використання матеріалів і результатів ландшафтного планування на робочих етапах розроблення територіальних планів залежить від завдань, що вирішуються на кожному з них. На інформаційно-аналітичному етапі використовують бази геоданих про природні умови і результати оцінювання значущості й чутливості ландшафтів. На конструктивному етапі розробки планувальних рішень аналізують і адаптують положення ландшафтного планування для визначення зон, пріоритетних для охорони природи і догляду за ландшафтом, які мають бути представлені в територіальних планах. Вперше реалізацію законодавчо зумовлених екологічних вимог у вітчизняному територіальному плануванні запропоновано здійснювати на основі ландшафтного планування. Представлено напрями і методичні підходи інтеграції ландшафтного планування у процес створення схем планування територій.

Ключові слова: ландшафтне планування; територіальне планування. 